\title{
Use of different urea levels in the feeding of Alpine goats
}

\section{Julicelly Gomes Barbosa ${ }^{1}$, Roberto Germano Costa ${ }^{2}$, Ariosvaldo Nunes de Medeiros ${ }^{3}$, Rita de Cássia Ramos do Egypto Queiroga ${ }^{4}$, Ângela Maria Vieira Batista ${ }^{5}$, Geovergue Rodrigues de Medeiros $^{6}$, Edvaldo Mesquita Beltrão Filho ${ }^{2}$}

\footnotetext{
${ }^{1}$ Programa de Doutorado em Zootecnia, PDIZ/UFPB, Areia-PB, Brasil.

2 Departamento de Agropecuária/CFT/UFPB, Bananeiras-PB, Brasil.

${ }^{3}$ Departamento de Zootecnia/CCA/UFPB, Areia-PB, Brasil.

${ }^{4}$ Departamento de Nutrição/CCS/UFPB, João Pessoa-PB, Brasil.

${ }^{5}$ Departamento de Zootecnia/UFRPE, Recife-PE, Brasil.

${ }^{6}$ Instituto Nacional do Semiárido (INSA), Campina Grande-PB, Brasil.
}

ABSTRACT - The objective of this study was to evaluate intake, apparent digestibility, ingestive behavior and blood parameters of milking goats fed cactus pear (Opuntia ficus indica) and increasing urea levels in substitution to soybean meal. Ten multiparous Alpine goats with average weight of $31 \pm 6.0 \mathrm{~kg}$ were used and distributed into $(5 \times 5)$ Latin squares and assessed during five 17-day periods, receiving five treatments with the following substitution levels: 0; 5; 10; $15 \mathrm{and} 20 \mathrm{~g} / \mathrm{kg}$ of urea. Neutral detergent fiber (NDF), non-fiber carbohydrates, ether extract, organic matter and water intake values showed differences, whith average values ranging from 1.03 to $1.13 ; 0.12$ to $0.14 ; 1.76$ to $2.10 \mathrm{~kg} / \mathrm{day}$ and 0.77 to $1.48 \mathrm{~kg} / \mathrm{day}$, respectively. The NDF and crude protein apparent digestibility values were significantly affected by urea levels. In relation to the ingestive behavior, the urea levels did not influence the feeding, idleness or rumination parameters. Difference was observed for the following physiological variables: feces frequency (11.5 to 15.9 times per day), urine frequency (10.8 to 14.2 times per day) and frequency of search for water (0.8 to 2.1 times per day). The urea levels influenced the blood parameters, whose average levels ranged from 29.83 to $40.76 \mathrm{mg} / \mathrm{dL}$. Pear cactus and increasing urea levels in substitution to soybean meal do not alter the dry matter intake or ingestive behavior. The use of urea associated with forage cactus reduces water intake and increases the blood urea concentration of milking goats.

Key Words: blood, DM intake, milking goats, rumination

\section{Introduction}

Dairy goat farming is an expanding activity in Brazil and plays an important economic and social role, especially in the Northeast.

However, despite its potential, its limiting factor is the adequacy of animal nutrition and its relation to production costs. Currently, strategies to reduce feeding costs have been the topic of numerous studies. Obtaining alternative feed, protein and energy source for goats in order to minimize the negative effects of the low fodder availability during the dry season on milk production has been a constant challenge.

Several ingredients destined to animal feeding, such as soybeans and corn, compete in importance with the human food chain. These products are often imported from other regions of the country at higher prices, thus increasing the costs of milk production.

In this scenario, the replacement of conventional feed ingredients for alternative feeds as sources of protein and energy is essential to the profitability of the dairy goat farming activity.

The use of urea as a source of non-protein nitrogen is one of the viable alternatives to reduce feeding costs. It is a compound highly soluble in the rumen, which produces ammonia, used by microorganisms for the synthesis of microbial protein. However, for proper use of urea, the synchrony of ammonia production with energy sources readily fermentable in the rumen is required.

When replacing conventional feed ingredients, one should take into account the changes caused in animal behavior, especially in relation to feed consumption, which is essential for nutrition, since it determines the level of nutrient intake and ultimately, the response of the animal.

Feed consumption and the study on the ingestive behavior are important parameters that contribute to ruminant nutrition research for the development of feeding systems, setting adjustments that improve animal production.

The objective of this study was to evaluate intake, apparent digestibility, ingestive behavior and blood 
parameters of milking goats fed increasing urea levels in substitution to soybean meal.

\section{Material and Methods}

The experiment was conducted at Universidade Federal da Paraiba, Campus of Bananeiras - PB, Brazil, whose geographical coordinates are $6^{\circ} 41^{\prime} 11^{\prime \prime S}$ and $35^{\circ} 37^{\prime} 41^{\prime \prime} \mathrm{W}$, and altitude of 552 meters.

The design was a $5 \times 5$ Latin square. Ten Alpine goats with $31 \pm 6 \mathrm{~kg}$ of body weight and $26 \pm 6$ days of lactation were used, with five treatments and five experimental periods. The treatments were $0,5,10,15,20 \mathrm{~g} / \mathrm{kg}$ of urea; the experimental period lasted 85 days, divided into five 17-day periods, the first 12 days of each period were used for the animals to adapt to diets and the last 5 days for sample collection.

The animals were managed in intensive system and placed in individual cages with slatted wooden floor of $1.26 \mathrm{~m}^{2}$, equipped with drinking and feeding troughs. The diets contained on average $12.7 \% \mathrm{CP}$, formulated to meet requirements of maintenance and lactation of goats (NRC, 1981). Feed was provided as a complete diet twice daily, at
7:30 am and 03:30 pm, immediately after milking, in amounts adjusted to provide around $15 \%$ of surplus, calculated from the daily consumption. The diets were composed of cactus forage, Tifton hay, corn, soy, urea and mineral supplement (Tables 1 and 2).

Feed samples, as well as leftovers and feces were collected in the collection days of each experimental period, then pre-dried and homogenized for obtainment of the composite sample. Dry matter (DM), ash, organic matter $(\mathrm{OM})$, crude protein (CP), neutral detergent fiber (NDF), acid detergent fiber (ADF) and ether extract (EE) were measured according to Silva \& Queiroz (2002). The levels of non-fiber carbohydrates (NFC) were evaluated according to the equation: $\mathrm{NFC}=100-(\mathrm{g} / \mathrm{kg} \mathrm{NDF}+\mathrm{g} / \mathrm{kg} \mathrm{CP}+\mathrm{g} / \mathrm{kg} \mathrm{EE}$ $+\mathrm{g} / \mathrm{kg}$ ash), which was proposed by Hall (2000). Chemical analysis was performed at the Laboratory of Animal Nutrition - Campus II - Universidade Federal da Paraíba.

To evaluate the apparent digestibility coefficients, feces were collected directly from rectal ampoule during 5 days of collection of each experimental period, collecting a sample of approximately $10 \%$ of the excreted volume and by the end of the collection period sample was collected for subsequent laboratory analysis. Samples of feces, feed and

Table 1 - Chemical composition of ingredients, on a dry matter basis

\begin{tabular}{|c|c|c|c|c|}
\hline Indicators & Crushed corn & Soybean meal & Tifton hay & Cactus pear \\
\hline Dry matter & 88.84 & 91.24 & 96.02 & 9.51 \\
\hline Organic matter & 97.34 & 92.84 & 93.45 & 80.26 \\
\hline Mineral matter & 2.65 & 7.16 & 6.54 & 12.74 \\
\hline Crude protein & 7.56 & 51.48 & 5.83 & 5.79 \\
\hline Ether extract & 3.06 & 2.37 & 1.16 & 1.77 \\
\hline NDF & 16.25 & 13.55 & 64.00 & 29.85 \\
\hline ADF & 5.87 & 9.76 & 35.38 & 18.43 \\
\hline NFC & 71.56 & 23.74 & 18.47 & 38.85 \\
\hline
\end{tabular}

NDF - neutral detergent fiber; ADF - acid detergent fiber; NFC - non-fiber carbohydrates.

Table 2 - Composition of ingredients in diets (g/kg DM), in function of the urea levels used

\begin{tabular}{|c|c|c|c|c|c|}
\hline \multirow[t]{2}{*}{ Ingredients } & \multicolumn{5}{|c|}{ Urea levels (g/kg) } \\
\hline & 0 & 5 & 10 & 15 & 20 \\
\hline Soybean meal & 140 & 110 & 80 & 50 & 20 \\
\hline Cactus pear & 265 & 275 & 285 & 295 & 305 \\
\hline Crushed corn & 290 & 305 & 320 & 334 & 350 \\
\hline Tifton hay & 290 & 290 & 289 & 289 & 287 \\
\hline Dry matter & 279.1 & 270.6 & 265.1 & 254.9 & 247.5 \\
\hline Organic matter & 897.1 & 891.9 & 895.8 & 895.5 & 893.7 \\
\hline Crude protein & 126.2 & 126.6 & 126.9 & 127.1 & 127.5 \\
\hline Eether extract & 20.2 & 20.1 & 20.0 & 11.9 & 11.9 \\
\hline Neutral detergent fiber & 330.8 & 332.1 & 332.8 & 336.0 & 334.3 \\
\hline Acid detergent fiber & 182.1 & 181.9 & 181.4 & 182.3 & 180.2 \\
\hline
\end{tabular}

DM - dry matter. 
leftovers were incubated in situ in nonwoven-fabric bags, (TNT - $100 \mathrm{~g} / \mathrm{m}^{2}$ ) for a period of 240 hours (Casali et al., 2008). The material remaining from incubation was subjected to extraction with acid detergent and the residue was called iADF. Fecal excretion was estimated through the relation between consumption and fecal concentration.

The observations concerning the ingestive behavior of animals were performed by using the instantaneous scanning method proposed by (Martin \& Bateson (1986) on the tenth day of each experimental period at intervals of five minutes for 24 hours and recorded in pre-designed forms. The behavioral variables were: standing idle (SDI), lying idle (LI), standing eating (SDE), standing ruminating (SDR) and lying ruminating (LR). Based on these data, on the average time in idleness, rumination and feeding, the number of times the animal defecated, urinated and sought water was continuously observed.

Water was provided ad libitum, and the consumption was quantified daily during the collection period. The daily evaporation rate was estimated by distributing buckets at different parts of the shed, so that the amount of water lost by evaporation could be verified on the next day and thus these losses were discounted from the consumption of animals.

Blood samples were collected from animals after morning milking on the last day of each experimental period, and through the jugular vein, blood was collected in sufficient amount to fill two $10 \mathrm{~mL}$ test BD Vacultainer ${ }^{\circledR}$ tubes 16 X100 mm in size without anti-coagulant, identified for each animal. After collection, the tubes were placed in centrifuge for 15 minutes at $5478 \mathrm{x}$ g. Soon after, about $5 \mathrm{~g}$ serum was removed from each sample and placed in tubes (Eppendorf) identified and stored in a freezer at $-20^{\circ} \mathrm{C}$ for further assessment of glucose and urea levels. The urea and glucose concentrations were determined using commercially available kits (LABTEST ${ }^{\circledR}$ Diagnostic Systems), using the enzymatic - colorimetric method.

The data were submitted to analysis of variance and regression, using the SAS software (Statistical Analysis System, version 8.0), adopting $\alpha=0.05$.

\section{Results and Discussion}

The effect of diets on dry matter intake (DMI) ranged from 1.97 to $2.31 \mathrm{~g} /$ day and 45.7 to $52.6 \mathrm{~g} / \mathrm{kg}$ CP (Table 3), indicating that the partial substitution of soybean meal by urea associated with cactus pear did not influence dry matter intake by animals.

Studying sources of non-protein nitrogen (NPN - urea and starea) to replace soybean meal in the diet of Saanen goats, Silva (2007) observed no change in dry matter intake, whose averages were $2.12 \mathrm{~kg} /$ day and $3.90 \%$ live weight (LW). Oliveira et al. (2001) observed decreased DM intake when urea was included in the diet at doses (1.4 and 2.1\%), similarly to the present study. Costa et al. (2009b) reported reduction in DM intake in milking goats with increasing dietary urea levels.

It was observed that the diet composition showed little variation (Table 2) with the addition of urea. Since cactus pear has high palatability (Ben Salem et al., 1996), the substitution of soybean meal by urea may not have shown any effect on DM intake, corroborating the findings of Bispo (2009), who studied total corn and partial soybean meal substitution by cactus pear and urea for milking cows.

The average percentages for DM intake ( $g / k g ~ B W)$ at all urea levels were similar to those recommended (NRC, 2007) for lactating goats on milk production of 1.5 liters/day, with $4 \%$ fat.

The intakes of crude protein (CP), neutral detergent fiber (NDF) and total digestible nutrients (TDN) were not

Table 3 - Average values for DM and nutrient intake according to the different levels of replacement of soybean meal by urea

\begin{tabular}{|c|c|c|c|c|c|c|c|c|c|}
\hline \multirow[t]{2}{*}{ Intake } & \multicolumn{5}{|c|}{ Urea levels (g/kg) } & \multirow[t]{2}{*}{ CV (\%) } & \multicolumn{3}{|c|}{$\mathrm{P}$ value } \\
\hline & 0 & 5 & 10 & 15 & 20 & & $\mathrm{~L}$ & $\mathrm{Q}$ & LA \\
\hline DM (g/day) & 2.10 & 2.15 & 2.31 & 2.14 & 1.97 & 13.59 & 0.266 & 0.063 & 0.210 \\
\hline $\mathrm{DM}\left(\mathrm{g} / \mathrm{kg}^{0.75}\right)$ & 125.4 & 126.4 & 135.1 & 122.0 & 117.0 & 19.87 & 0.879 & 0.754 & 0.654 \\
\hline CP (kg/day) & 0.27 & 0.28 & 0.30 & 0.27 & 0.27 & 13.08 & 0.956 & 0.112 & 0.521 \\
\hline NDF (kg/day) & 0.54 & 0.54 & 0.64 & 0.59 & 0.52 & 14.73 & 0.137 & 0.046 & 0.784 \\
\hline $\operatorname{EE}(\mathrm{kg} / \text { day })^{2}$ & 0.13 & 0.13 & 0.14 & 0.12 & 0.12 & 9.24 & 0.324 & 0.023 & 0.731 \\
\hline $\mathrm{OM}(\mathrm{kg} / \mathrm{day})^{3}$ & 1.88 & 1.91 & 2.10 & 1.85 & 1.76 & 14.24 & 0.112 & 0.050 & 0.762 \\
\hline TDN (kg/day) & 1.21 & 1.34 & 1.41 & 1.32 & 1.32 & 11.45 & 0.131 & 0.098 & 0.544 \\
\hline
\end{tabular}

DM - dry matter; CP - crude protein; NDF - neutral detergent fiber; NFC - non-fibrous carbohydrates; EE - ether extract; OM - organic matter; TDN - total digestible nutrients; CV - coefficient of variation; L and Q - linear and quadratic effects of inclusion of urea in the diet; LA - lack of adjustment.

$1 \hat{\mathrm{Y}}=1.0309+0.1486 \mathrm{x}-0.0743 \mathrm{x}^{2}\left(\mathrm{r}^{2}=0.77\right)$.

$2 \hat{Y}=0.1297+0.0111 \mathrm{x}-0.0086 \mathrm{x}^{2}\left(\mathrm{r}^{2}=0.55\right)$.

$3 \hat{\mathrm{Y}}=1.8629+0.3286 \mathrm{x}-0.1943 \mathrm{x}^{2}\left(\mathrm{r}^{2}=0.67\right), \mathrm{P}<0.05$. 
affected $(\mathrm{P}>0.05)$ by the urea levels possibly due to the behavior observed in the DM intake. For the intakes of non-fibrous carbohydrates (NFC), ether extract (EE) and organic matter $(\mathrm{OM})$, a difference $(\mathrm{P}<0.05)$ was observed between the urea levels. The averages ranged from 1.03 to $1.13,0.12$ to $0.14,1.76$ to $2.10 \mathrm{~kg} /$ day, respectively. All these variables showed a decrease from the level of $10 \mathrm{~g} / \mathrm{kg}$ of urea, probably due to the bitter taste and low palatability of urea. Similar behavior was found by Melo et al. (2003a), assessing the effects of the partial substitution of soybean meal by urea and forage cactus on the performance of Holstein cows.

The voluntary water intake (Table 4) had a decrease $(\mathrm{P}<0.05)$ between treatments due to the increased participation of cactus pear (Table 2) in diets. The mean values ranged from 1.48 to $0.77 \mathrm{~kg} /$ day. This behavior is due to the amount of water present in cactus pear, resulting in a decreased amount of water consumed directly from the troughs (Arnaud et al. 2005; Cavalcanti et al., 2008, França et al., 2009). Accordingly, Vieira et al. (2008) reported that the main way of obtaining water is by direct swallowing due to daily rhythms of drinking water; however, when they eat succulent feed, the water consumption can be very low or absent. According to Arnaud et al. (2005), Ben Salem et al. (2005) and Costa et al. (2009a), the addition of cactus pear in the diet reduced the need for water consumption for cows, goats and sheep, respectively.

The total water intake in relation to substitution levels had a quadratic effect $(\mathrm{P}<0.05)$, with average values from 7.37 to $8.36 \mathrm{~kg}$ of water consumed daily. The total water intake was higher than the recommended by international committees for goats (NRC, 2007).

The voluntary water intake per $\mathrm{kg}$ of $\mathrm{DM}$ intake (VWI:DM intake) showed a quadratic effect $(\mathrm{P}<0.01)$ for the respective treatments. However, the total water intake per kilogram of DM intake showed increasing linear effect $(\mathrm{P}<0.01)$, whose average values ranged from 2.96 to $3.28 \mathrm{~kg}$ of water in treatments. According to the NRC (2001), this influence is due to the amount of dry matter in the diet, influencing the frequency of water intake by animals.

The apparent CP digestibility increased linearly $(\mathrm{P}<0.01)$ and the apparent NDF digestibility showed quadratic effect $(\mathrm{P}<0.01)$ (Table 5 ) with the substitution of soybean meal by urea.

This increased effect of the apparent CP digestibility with increasing urea levels in substitution to soybean meal can be credited to the higher digestibility of urea compared with soy protein, corroborated by Santos et al. (1998), who compared sources of degraded protein in the rumen (urea, soybean meal and fishmeal) and observed higher CP digestibility in the diet with urea. As there was an increase of urea level in the blood of animals (Table 8), it is likely that there was a greater recycling of $\mathrm{N}$ in the liver by increasing the blood urea concentration, decreasing the $\mathrm{N}$ excretion with the return of urea to the rumen, increasing the protein digestibility.

On the other hand, urea is soluble, and in the rumen, it is rapidly hydrolyzed into ammonia, which makes it necessary to provide a simultaneous source of energy readily available so that microorganisms can efficiently use this ammonia as it is released. The NFC from cactus pear was the source of carbon (energy) required for growth of microorganisms and thus contributes to the increase in the CP digestibility.

Because cactus pear was introduced at increasing levels in treatments (Table 2) and it has a high pectin content, about 23.3\% (Melo et al., 2003b), Antunes et al. (2011) reported that fermentation of pectin provides better rumen environment, increasing the production of acetate, which

Table 4 - Water intake of goats fed urea as a substitute for soybean meal

\begin{tabular}{|c|c|c|c|c|c|c|c|c|c|}
\hline \multirow[t]{2}{*}{ Variables } & \multicolumn{5}{|c|}{ Urea levels (g/kg) } & \multirow[t]{2}{*}{ CV (\%) } & \multicolumn{3}{|c|}{$\mathrm{P}$ value } \\
\hline & 0 & 5 & 10 & 15 & 20 & & $\mathrm{~L}$ & $\mathrm{Q}$ & LA \\
\hline $\mathrm{VWI}^{1}$ & 1.48 & 1.31 & 1.14 & 0.77 & 0.89 & 35.15 & 0.020 & 0.414 & 0.656 \\
\hline HW I & 0.24 & 0.25 & 0.27 & 0.24 & 0.22 & 11.96 & 0.153 & 0.808 & 0.544 \\
\hline $\mathrm{CWI}^{3}$ & 0.94 & 0.94 & 0.99 & 0.86 & 0.81 & 12.04 & 0.401 & 0.031 & 0.211 \\
\hline $\mathrm{TWI}^{4}$ & 7.70 & 7.85 & 8.36 & 7.41 & 7.37 & 11.91 & 0.430 & 0.020 & 0.451 \\
\hline
\end{tabular}

CV - coefficient of variation; L and Q - linear and quadratic effects of inclusion of urea in the diet; LA - lack of adjustment. VWI - voluntary water intake (kg/day), CWI - cactus water intake (kg); HWI - hay water intake (kg), CWI - concentrate water intake (kg) TWI - total water intake (kg) VWI:DMI - voluntary water intake:DM intake ratio (kg) TWI:DMI - total water intake:DM intake ratio $(\mathrm{kg})$.

$1 \hat{\mathrm{Y}}=1.462-0.344 \mathrm{x}\left(\mathrm{r}^{2}=0.86\right)$.

$2 \hat{\mathrm{Y}}=5.0051+1.2514 \mathrm{x}-0.5257 \mathrm{x}^{2}\left(\mathrm{r}^{2}=0.75\right)$

$3 \hat{\mathrm{Y}}=0.936+0.092 \mathrm{x}-0.08 \mathrm{x}^{2}\left(\mathrm{r}^{2}=0.83\right)$

$4 \hat{Y}=7.6951+0.8314 x-0.5257 x^{2}\left(r^{2}=0.60\right)$

$5 \hat{Y}=0.7391-0.3926 \mathrm{x}+0.1143 \mathrm{x}^{2}\left(\mathrm{r}^{2}=0.95\right)$.

$6 \hat{\mathrm{Y}}=2.96+0.16 \mathrm{x}\left(\mathrm{r}^{2}=0.99\right) ; \mathrm{P}<0.05$ and $\mathrm{P}<0.01$. 
Table 5 - Apparent digestibility coefficients of dry matter and nutrients of goats under the effect of urea levels

\begin{tabular}{|c|c|c|c|c|c|c|c|c|c|}
\hline \multirow[t]{2}{*}{ Item } & \multicolumn{5}{|c|}{ Urea levels (g/kg) } & \multirow[t]{2}{*}{ CV (\%) } & \multicolumn{3}{|c|}{$\mathrm{P}$ value } \\
\hline & 0 & 5 & 10 & 15 & 20 & & L & Q & LA \\
\hline DMad & 0.544 & 0.580 & 0.561 & 0.557 & 0.588 & 10.18 & 0.171 & 0.878 & 0.472 \\
\hline $\mathrm{CPad}^{1}$ & 0.545 & 0.582 & 0.556 & 0.550 & 0.646 & 9.52 & 0.001 & 0.268 & 0.348 \\
\hline EEad & 0.865 & 0.886 & 0.843 & 0.831 & 0.840 & 6.72 & 0.162 & 0.810 & 0.390 \\
\hline $\mathrm{NDFad}^{2}$ & 0.581 & 0.546 & 0.528 & 0.517 & 0.572 & 6.23 & 0.320 & 0.001 & 0.233 \\
\hline
\end{tabular}

ad - apparent digestibility; DM - dry matter; OM - organic matter; CP - crude protein; EE - ether extract; NDF - neutral detergent fiber; NFC - non-fibrous carbohydrates; TDN - total digestible nutrients; CV - coefficient of variation; L and Q - linear and quadratic effects of inclusion of urea in the diet; LA - lack of adjustment.

$1 \hat{\mathrm{Y}}=0.5418+0.0344 \times\left(\mathrm{r}^{2}=0.42\right)$

$2 \hat{\mathrm{Y}}=0.5849-0.1163 \mathrm{x}+0.0534 \mathrm{x}^{2}\left(\mathrm{r}^{2}=0.90\right)$.

is the main volatile fatty acid produced by rumen microorganisms and most important source of metabolizable energy for rumen bacteria. Dusková \& Marounek (2001) studied the digestion process of starch and pectin and found increased production of acetate with the use of pectin in the fermentation process.

The increasing urea levels as a substitute for soybean meal influenced $(\mathrm{P}<0.01)$ the apparent NDF digestibility and increased the TDN levels ( 0.583 to $0.667 \mathrm{~g} / \mathrm{kg}$ ), probably caused by the increase in the dietary NFC content (Table 2). Adequate proportions of intermediate and fast fermentation carbohydrate maximize the use of urea, which in turn increases the digestibility of the dietary fiber by increasing the population of rumen microorganisms.

The urea levels did not affect $(\mathrm{P}>0.05)$ any of the variables because the DM and NDF intake was not affected with the addition of increasing urea levels (Table 6). The averages for feeding, idleness and rumination were 5.41, 11.12 and 7.40 hours/day, respectively.

These results are similar to those obtained by Pires et al. (2001), in which the time available for feed consumption ranged from 40 to 10 hours per day, more intense after milking. In the same sense, the results shown for idleness were similar to those reported by Orr et al. (2001), who reported that idleness can account for up to 10 hours, varying between 9 and 12 hours.

The experimental diets used had similar neutral detergent fiber levels (NDF) (Table 2), not affecting ( $\mathrm{P}>0.05$ ) rumination times. The values obtained were similar to those reported by Church (1988) for goats, of $446 \mathrm{~min} /$ day (7.43 h/day) for rumination.

Substitution levels of soybean meal by urea affected $(\mathrm{P}<0.05)$ variables fecal frequency, urine excretion and search for water (Table 7).

There was a reduction in the search for water from 2.1 to 0.8 times/day due to the increase in dietary forage cactus levels. Consequently, there was an increased urine frequency (10.8 to 14.2 times/day), in agreement with Costa et al. (2009a), who observed the same reduction as that reported in this study. This reduction in the search for water is due to the high water content in the cactus pear, and this increase reduces the need of animals to search for it.

The main way of obtaining water is by direct swallowing due to daily rhythms of drinking water. According to Reece (2004) when they eat succulent feed, the water consumption can be very low or absent, and under these conditions, the animal excretes a considerable amount of urine as a result of overhydration to regulate the volume of body water.

For the physiological variable feces excretion, it was found that as the dietary urea and cactus pear increased (Table 2), the number of times the animal defecated also increased. This was probably due to the increased passage of feed in animals that received higher amounts of cactus pear in their diet.

The substitution of soybean meal by increasing urea levels interfered $(\mathrm{P}<0.05)$ with the variable urea (Table 8).

Table 6 - Average values of variables of time spent on feeding, idleness and rumination, expressed in hours/day for milking goats according to the replacement level of soybean meal by urea

\begin{tabular}{|c|c|c|c|c|c|c|c|c|c|}
\hline \multirow[t]{2}{*}{ Item } & \multicolumn{5}{|c|}{ Urea levels (g/kg) } & \multirow[t]{2}{*}{ CV (\%) } & \multicolumn{3}{|c|}{$\mathrm{P}$ value } \\
\hline & 0 & 5 & 10 & 15 & 20 & & $\mathrm{~L}$ & $\mathrm{Q}$ & LA \\
\hline Feeding & 5.43 & 5.30 & 5.21 & 5.48 & 5.64 & 13.60 & 0.423 & 0.294 & 0.404 \\
\hline Rumination & 7.27 & 7.34 & 7.69 & 7.46 & 7.26 & 29.07 & 0.822 & 0.482 & 0.577 \\
\hline
\end{tabular}

CV - coefficient of variation; L and Q - linear and quadratic effects of inclusion of urea in the diet; LA - lack of adjustment. 
The mean glucose values ranged from 50.31 to $53.25 \mathrm{mg} / \mathrm{dL}$ between the urea levels. According to Silva (2007), among the various metabolites used as fuel for respiratory oxidation, glucose is considered the most important; it is vital for functions such as brain metabolism and lactation. According to Santos et al. (1998), the manipulation of sources and levels of dietary protein hardly affects the plasma glucose levels.

Blood urea concentrations ranged incrementally (from 29.83 to $40.76 \mathrm{mg} / \mathrm{dL}$ ); there was probably a greater $\mathrm{N}$ recycling in the liver of animals by increasing the blood urea concentration. This variation in the plasma urea levels was provided by increasing the dietary urea levels of goats, with greater amount of ammonia produced in the rumen, as a result of the increased NPN levels as the urea consumption increases (Vilela et al. 2005). As described by Van Soest (1994), high dietary nitrogen level causes a greater flow of this nutrient to tissues and liver, and from liver to blood.

Matarazzo et al. (2006) found variations in the plasma urea levels from 19.23 to $43.54 \mathrm{mmol} / \mathrm{dL}$ with the inclusion of dietary urea ranging from 0 to $2 \%$. Silva (2007) assessed the substitution of soybean meal by urea or starea in the feeding of lactating goats and found that the circulating urea was higher in goats fed with diet where soybeans were substituted by urea, indicating that higher amounts of available nitrogen may have been excreted, thus reducing the efficiency of its use.

Table 7 - Average values of physiological variables, feces frequency, urine excretion and search for water in number of times per day in function of the replacement levels of soybean meal by urea for milking goats

\begin{tabular}{|c|c|c|c|c|c|c|c|c|c|}
\hline \multirow[t]{2}{*}{ Item } & \multicolumn{5}{|c|}{ Urea levels (g/kg) } & \multirow[t]{2}{*}{ CV (\%) } & \multicolumn{3}{|c|}{$P$ value } \\
\hline & 0 & 5 & 10 & 15 & 20 & & $\mathrm{~L}$ & Q & LA \\
\hline Feces $^{1}$ & 12.9 & 11.5 & 13.1 & 12.9 & 15.9 & 23.40 & 0.025 & 0.068 & 0.157 \\
\hline Urine $^{2}$ & 11.5 & 10.8 & 12.3 & 13.5 & 14.2 & 21.70 & 0.006 & 0.442 & 0.170 \\
\hline Water ${ }^{3}$ & 1.4 & 2.1 & 1.8 & 0.8 & 0.8 & 71.85 & 0.018 & 0.086 & 0.720 \\
\hline
\end{tabular}

$\mathrm{CV}$ - coefficient of variation; L and Q - linear and quadratic effects of inclusion of urea in the diet; LA - lack of adjustment.

$1 \hat{\mathrm{Y}}=11.78+1.48 \mathrm{x}\left(\mathrm{r}^{2}=0.53\right)$.

$2 \hat{\mathrm{Y}}=10.84+1.62 \mathrm{x}\left(\mathrm{r}^{2}=0.84\right)$.

$3 \hat{\mathrm{Y}}=1.88-0.5 \mathrm{x}\left(\mathrm{r}^{2}=0.45\right) . \mathrm{P}<0.01 ; \mathrm{P}<0.05$

Table 8 - Average values of blood parameters according to the replacement levels of soybean meal by urea

\begin{tabular}{|c|c|c|c|c|c|c|c|c|c|}
\hline \multirow[t]{2}{*}{ Item $(\mathrm{mg} / \mathrm{dL})$} & \multicolumn{5}{|c|}{ Urea levels (g/kg) } & \multirow[t]{2}{*}{ CV (\%) } & \multicolumn{3}{|c|}{$\mathrm{P}$ value } \\
\hline & 0 & 5 & 10 & 15 & 20 & & $\mathrm{~L}$ & Q & LA \\
\hline Glucose & 50.31 & 55.66 & 51.68 & 50.55 & 53.25 & 7.71 & 0.142 & 0.243 & 0.369 \\
\hline Urea $^{1}$ & 29.83 & 30.65 & 31.00 & 38.77 & 40.76 & 15.42 & 0.025 & 0.264 & 0.421 \\
\hline
\end{tabular}

$\mathrm{CV}$ - coefficient of variation; $\mathrm{L}$ and Q - linear and quadratic effects of inclusion of urea in the diet; LA - lack of adjustment.

${ }^{1}$ Regression: $\hat{Y}=28.206+5.996 x\left(r^{2}=0.85\right) ; P<0.05$.

\section{Conclusions}

Urea levels up to $20 \mathrm{~g} / \mathrm{kg}$ in substitution for soybean meal do not change intake or apparent digestibility and do not interfere with the ingestive behavior, promoting increased blood urea concentration and a decrease in the water consumption of milking goats.

\section{References}

ARNAUD, B.L.; VÉRAS, A.S.C.; FERREIRA, M.A. et al. Efeitos da substituição do feno de capim-tifton e do farelo de milho pela palma forrageira e pelo farelo de soja sobre a ingestão de alimentos e parâmetros fisiológicos. Acta Scientiarum. Animal Sciences, v.27, n.4, p.475-482, 2005.

BEN SALEM, H.; ABDOULI, H.; NEFZAOUI, A. et al. Nutritive value, behaviour, and growth of Barbarine lambs fed on oldman saltbush (Atriplex nummularia L.) and supplemented or not with barley grains or spineless cactus (Opuntia ficusindica $\mathrm{f}$. inermis) pads. Small Ruminant Research, v.59, n.2-3, p.229-237, 2005.

BEN SALEM, H.; NEFZAOUI, A.; ABDOULI, H. et al.Effect of increasing level of spinelles cactus (Opuntia ficus-indica var.inermis) on intake and digetion by sheep feed given strawbased diets. Journal of Animal Science, v.62, n.1, p.293-299, 1996.

ANTUNES, R.C.; RODRIGUEZ, N.M.; SALIBA, E.O.S. Metabolismo de carboidratos não estruturais. In: BERCHIELLI, T.T.; PIRES, A.V.; OLIVEIRA, S.G. (Eds.) Nutrição de ruminantes. 2.ed. Jaboticabal: Funep, 2011. p.239-263.

BISPO, S.V. Substituição total do milho e parcial do farelo de soja por palma forrageira e uréia para vacas em lactação. 2009. 53f. Tese (Doutorado em Zootecnia) - Universidade Federal Rural de Pernambuco, Recife.

CASALI, A.O.; DETMAN, E.; VALADARES FILHO, S.C. et al. Influência do tempo de incubação e do tamanho de partículas sobre os teores de compostos indigestíveis em alimentos e fezes bovinas obtidos por procedimentos in situ. Revista Brasileira de Zootecnia, v.37, n.2, p.335-342, 2008. 
CAVALCANTI, C.V.A.; FERREIRA, M.A.; CARVALHO, M.C. et al. Palma forrageira enriquecida com uréia em substituição ao feno de capimtifton 85 em rações para vacas da raça Holandesa em lactação. Revista Brasileira de Zootecnia, v.37, n.4, p.689-693, 2008.

CHURCH, D.C. El ruminat: fisiología digestiva y nutrición. Zaragoza: Acribia. 1988. 641p.

COSTA, R.G.; BELTRÃO FILHO, E.M.; MEDEIROS, A.N. et al. Effects of increasing levels of cactus pear (Opuntia ficus-indica L. Miller) in the diet of dairy goats and its contribution as a source of water. Small Ruminant Research, v.82, n.1, p.62-65, 2009a.

COSTA, R.G.; BELTRÃO FILHO, E.M.; QUEIROGA, R.C.R.E. et al. Partial replacement of soybean meal by urea on production and milk physicochemical composition in Saanen goats. Revista Brasileira de Saúde e Produção Animal, v.10, n.3, p.596-603, 2009b.

DUSKOVÁ, D.; MAROUNEK, M. Fermentation of pectin and glucose, and activity of pectin-degrading enzymes in the rumen bacterium Lachnospira multiparus. Letters in Applied Microbiology, v.33, n.2, p.159-163, 2001.

FRANÇA, S.R.L.; GONZAGA NETO, S.; PIMENTA FILHO, E.C. et al.Comportamento ingestivo de ovelhas Morada Nova no terço final de gestação com níveis de energia metabolizável na dieta ingestive behavior of Morada Nova. Revista Brasileira de Saúde e Produçao Animal, v.10, n.1, p.73-84, 2009.

HALL, M.B. Calculation of non-structural carbohydrate content of feeds that contain non-protein nitrogen. Gainesville: University of Florida, 2000. p.A-25 (Bulletin, 339).

MARTIN, P.; BATESON, P. Measuring behavior: an introductory guide. 3.ed. New York: Cambridge University Press, 1986. 200p.

MATARAZZO. S.V.; MATTOS, W.R.S.; SUCUPIRA, M.C.A. et al. Teores de uréia em dietas com cana de açucar: fermentação ruminal e concentração de uréia plasmática em vacas leiteiras. Boletim da Indústria Animal, v.63, n.3, p.143-149, 2006.

MELO, A.A.S.; FERREIRA, M.A.; VERAS, A.S.C. et al. Substituição do farelo de soja por uréia e palma forrageira (Opuntia fícus indica Mill) em dietas para vacas em lactação. I. Desempenho. Revista Brasileira de Zootecnia, v.32, n.3, p.727-736, 2003a.

MELO, A.A.S.; FERREIRA, M.A.; VÉRAS, A.S.C. et al. Substituição parcial do farelo de soja por uréia e palma forrageira em dietas para vacas em lactação. Digestibilidade. Acta Scientiarum. Animal Sciences, v.25, n.2, p.339-345, 2003b.
NATIONAL RESEARCH COUNCIL - NRC. Nutrient requirements of goats. Washington, D.C.: National Academy Press, 1981. 91p.

NATIONAL RESEARCH COUNCIL - NRC. Nutrient requirements of the dairy cattle. 7.ed. Washington, D.C.: 2001. 381p.

NATIONAL RESEARCH COUNCIL - NRC. Nutrient requirements of small ruminants. Washington: National Academy Press, 2007. 362p.

OLIVEIRA, A.S.; VALADARES, R.F.D.; VALADARES FILHO, S.C. et al. Consumo, digestibilidade, produção e composição do leite em vacas alimentadas com quatro níveis de compostos nitrogenados não-protéicos. Revista Brasileira de Zootecnia, v.30, n.4, p.1358-1366, 2001.

ORR, R.J.S.; RUTTER, S.M.; PENNING, P.D. et al. Matching grass supply to grazing patterns for dairy cows. Grass and Forage Science, v.56, n.35, p.352-361, 2001.

PIRES, M.F.A.; VileLA, D.; ALVIM, M.J. Comportamento alimentar de vacas holandesas em sistemas de pastagens ou em confinamento. Juiz de Fora: Embrapa Gado de Leite, 2001. 2p. (Boletim Técnico, 2).

REECE, W.O. Dukes'physioplogy of domestic animals. 12.ed. Ithaca: Cornell University Press, 2004. 999p.

SANTOS, F.A.P. HUBER, J.T.; THEURER, C.B. et al. Milk yield and composition of lactation cows fed steam-flaked Sorghum and graded concentrations of ruminal degradable protein. Journal Dairy Science, v.81, n.1, p.215-222, 1998.

SILVA, D.J.; QUEIROZ, A.C. Análise de alimentos: métodos químicos e biológicos. Viçosa, MG: Imprensa Universitária, 2002. 165p.

SILVA, M.G.C.M. Influência de fontes de nitrogênio na dieta de cabras Saanen, sobre o desempenho, concentrações de glicose e ureia no sangue e composição do leite. 2007. 104f. Tese (Doutorado em Zootecnia) - Universidade Federal de Lavras, Lavras.

VAN SOEST, P.J. Nutritional ecology of the ruminant. 2.ed. Ithaca: Cornell University Press. 1994. 476p.

VIEIRA, E.L.; BATISTA, A.M.V.; GUIM, A. et al. Effects of hay inclusion on intake, in vivo nutrient utilization and ruminal fermentation of goats fed spineless cactus (Opuntia fícus-indica Mill) based diets. Animal Feed Science and Technology, v.141, n.4, p.199-208, 2008.

VILELA, F.G.; TEIXEIRA, J.C.; REIS, S.T. Efeito da substituição do farelo de soja pela amiréia $150 \mathrm{~S}$ nos parâmetros sanguíneos, consumo, produção e composição do leite de vacas Girolandas. Revista Ceres, v.52, n.300, p.275-291, 2005. 